腎細胞癌患者における胎盤型膜結合性アリル

$$
\text { アミダーゼの出現に関する研究 }
$$

\author{
爱蝯大学医学部第二内科 \\ 横山マサ子 日和田邦男 ${ }^{\diamond}$ 国府 達郎
}

\title{
A PLACENTAL TYPE OF MEMBRANE-BOUND ARYLAMIDASE FOUND IN PATIENTS WITH RENAL CELL CARCINOMA
}

Masako YoKovama, MD, Kunio Hiwada, MD and Tatsuo KoKubu, MD

The Second Department of Internal Medicine, Ehime University School of Medicine, Ehime

\begin{abstract}
概要 私達は腎細胞癌 7 例の組織（全例淡明細胞癌）から膜結合性アリルアミダーゼをトリプシンで 溶出させ，5例（すなわち71\%）に胎盤型膜結合性アリルアミダーゼの出現を認めた．さらに第 1 症 例で，腹水と血清中に癌組織中のものと同じ胎盤型膜結合性アリルアミダーゼを証明した。胎盤型膜 結合性アリルアミダーゼが出現した 5 例は近接あるいは遠隔いずれかに転移を認めた。しかし手術の 時点で転移が証明できなかつた残り 2 例からは正常腎由来の膜結合性フリルアミダーゼしか認められ なかつた，私達は癌組織に打ける胎盤型フリルアミダーゼの出現を, 癌化によるフインエンザイムの 偏倚と考光，この酵素を第 1 症例の患者名にちなんてShiba-isoenzyme と命名した。
\end{abstract}

\section{はじめに}

膜結合性アリルアミダーゼ（EC 3，4，11， 2) (以下Mb-AAと略す) は, 古典的にロイシ ンフミノペプチダーゼ（EC 3，4，11，1）と呼 ばれる酵素之は異なつている。私達は七ト小腸， 肺, 肝, 腎扣よび胎盤組織の膜成分から本醭素 をトリプシンで溶出し，それぞれ臓器固有のフ イソェンザイムであることを明らかにしだ．－ 方私達が最初に入手した腎細胞癌組織から溶出し たMb-AAは，正常腎由来のMb-AA とは電気泳動 の易動度，耐熱性の点で異なり，化学的な諸性質 はむしろ胎盤由来のMb-AAによく似ていること

[昭和53年10月 23 日受稿]

本研究の要旨は第21回日本腎䁍学会総会および第76 回日本内科学会講演会（昭和54年 4 月 5 日）にて発表 した。
から，癌性胎盤型偏倚に基づくアイソェンザイム である可能性を発表してきた ${ }^{2)}$ ），今回は腎細胞 癌 7 例と，第 1 症例の剖検時に得た転移組織, 血 清括よび腹水を材料として，Mb-AAの胎盤型へ の偏倚の頻度と血中などへの出現について研究し た成績を報告する。

\section{材料と方法}

酵素材料：腎細胞癌組織は手術時に得たもの を直ちに $-20^{\circ} \mathrm{C} て ゙$ 凍結保存しこれを材料とし た。すた第 1 症例の剖検時に得た血清，腹水およ び肝転移組織を用いた．胎盤は正常分婏胎盤を用 いまた正常腎組織は癌手術のため偏腎摘出した 腎の正常部分および法医解剖時に得たものを材料 とした。な㧧本酵素は非常に安定であり，材料の 出所が異なつてる酵素活性の大きな失活は認めら れなかつた。 
試薬： L-alanyl- $\beta$-naphtylamide, L-leucyl-4methoxy- $\beta$-naphtylamide 塩酸塩, Fast Blue B塩 はSigma社 (St. Louis, Mo., アメリカ) から購入 した. トリプシンはDifco Laboratories(Detroit, Mich., アメリカ) より, Sephadex G-200, concanavalin A-Sepharose 4BはPharmacia社 (Uppsala，スェーデン)，分子量測定用キットはBoehringer社 (Manheim, 西ドイッ), ampholine $\mathrm{pH}$ 3.5 5.0, pH 6.0 8.0はLKB社 (Bromma, スエ ーデン)より購入した。 DE52はWhatmman社 (Maidstone, Kent, イギリス), p-dimethylaminocinnamaldehydeは第一化学薬品 (東京), ポリア クリルアミドディスク電気泳動に用いた各試薬お よびsodium dodecylsulfate(SDS) と $\alpha$-D-methylmannosideは和光純薬（大阪）から購入した。

酵素活性測定法：酵素活性の測定は，Lalanyl- $\beta$-naphtylamideを基質に用いて松谷らの方 法卓で測定した。

組䥫からの酵素精製法：腎細胞癌組織は肉眼 的に董瘍部分のみを切り取り, 3 倍容の $0.1 \mathrm{M}$ 卜 リス塩酸緩衝液, $\mathrm{pH} 7.3$ ボホジナイズし, 1,000 × g，15分遠心した。この上清を酶酸でpHを5.0
に調整し，8,000×g，15分遠心後，沈渣に0.1M トリス塩酸緩衝液PH 8.0を加え, トリプシン・ト ルエン処理で（トリプシン：蛋白= $1: 20 ） \mathrm{Mb}$ AAを溶出した。これをSephadex G-200カラムで さらに精製したるのを䣼素材料とした，腎細胞癌 転移組織, 胎盤揖よび正常部腎組織についても同 様の方法で酵素材料を得た。

血清と腹水からの酵素精製法 : 血清と腹水は 各々 $100 \mathrm{ml}$ を硫安 45 ～ $80 \%$ で塩析した．活性部分 をDE52によるカラムクロマトグラフィーを行な い，0〜0.3M食塩の直線勾配法で溶出した。 さら に活性部分をconcanavalin A-sepharose 4Bカラム にて精製 $(0.1 \mathrm{M} \alpha$-D-methylmannosideにて活性 は溶出）した。この 3 段階で比活性は血清, 腹水 中の本酵素活性とす約 500 倍に上昇した。

ポリアクリルアミド電気泳動： $6.5 \%$ ポリフ クリルアミドゲルディスク電気泳動はゲル 1 本当 り2.5mAの電流を通じ，4 時間泳動を行なつた。 ゲルの酵素活性部位の発色はNachlasらの変法")を 用いた。

Isoelectric focusing法：LKB 110カラムを 用いて 庶糖密度勾配法による1\%アンホライン

表 1 . 症例概要

\begin{tabular}{|c|c|c|c|c|c|c|c|c|c|c|c|c|}
\hline \multirow{2}{*}{ 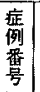 } & \multirow{2}{*}{$\begin{array}{l}\text { 氏 } \\
\text { 名 }\end{array}$} & \multirow{2}{*}{ 性 } & \multirow{2}{*}{\begin{tabular}{|l|} 
年 \\
令 \\
\end{tabular}} & \multirow{2}{*}{\multicolumn{2}{|c|}{\begin{tabular}{|c|}
$\begin{array}{c}\text { specific activity } \\
\mu \mathrm{mol} / \mathrm{min} / \mathrm{mg}\end{array}$ \\
homogenized gel filt rated \\
\end{tabular}}} & \multirow{2}{*}{ 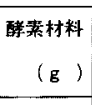 } & \multicolumn{2}{|c|}{ 宦気泳䣦 } & \multicolumn{2}{|c|}{ 檕 移 } & \multirow{2}{*}{\multicolumn{2}{|c|}{\begin{tabular}{|l|l|}
\multicolumn{2}{|c|}{ 陪 床 症 状 } \\
血尿 &
\end{tabular}}} \\
\hline & & & & & & & 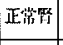 & 胎盤 & 近援 & 遠雨 & & \\
\hline 1 & A S & 9 & 59 & 0.0046 & 6.1 & 18.5 & & - & - & $\bullet$ & . & $\begin{array}{l}\text { 器熱 } \\
\text { 篮 }\end{array}$ \\
\hline 2 & K T & 움 & 70 & 0.003 & 1.3 & 21.4 & $\bullet$ & - & • & & - & \\
\hline 3 & K M & $\hat{\delta}$ & 44 & 0.051 & 1.23 & 29.0 & & - & - & & - & 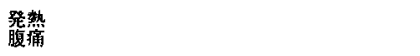 \\
\hline 4 & T K & 우 & 52 & 0.16 & 1.19 & 45.0 & - & & & & - & 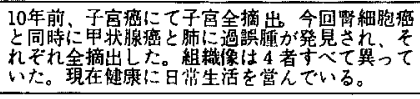 \\
\hline 5 & MI & 우 & 8 & 0.198 & 2.95 & 5.2 & - & & & & - & 股部陑潜 \\
\hline 6 & Y W & s & 62 & 0.043 & 3.45 & 18.0 & & - & - & & - & 腹涌 \\
\hline 7 & K T & $\hat{s}$ & 65 & 0.0029 & 4.9 & 33.5 & - & - & • & - & & 枟移による病的骨折 \\
\hline
\end{tabular}

で示したところは上記項目の存在を示す) 
$\mathrm{pH} 3.5 \sim 5.0$ でェレクトロフォーカシングを行なつ た。.

蛋白定量： 蛋白量はLowry法")で測定した。

\section{成 績}

表 1 に 7 症例 の 概要を示した。男 3 例女 4 例 で，平均年令は51才（第 5 症例を除くと59才）で あつた．組織型は全例淡明細胞癌であつた。

1. ポリアクリルアミドゲル電気泳動による解 析

電気泳動の成績を図 1 に示した。 No.1は正常 腎由来のMb-AAであり，No.5は胎盤由来のMbAAである．No. 4の位置にバンドが出現 したも のは第 $1,3,6$ 症例で, これはNo.5の胎盤由 来のむのと一致する．No. 2の位置にバンドが泳 動されたものは第 4, 5 症例で，これは正常腎由 来のものと一致する. No. 3の位置にバンドが出 現したのが第 $2 ， 7$ 症例 で，これは胎盤由来の Mb-AA と 正常腎由来のMb-AAのものに一致する 両者のバンドを含んでいる. しかしこの場合肉眼 的には腫瘍部のみを取り出したが，組織学的には 正常腎組織が混入していた可能性も考えられる.

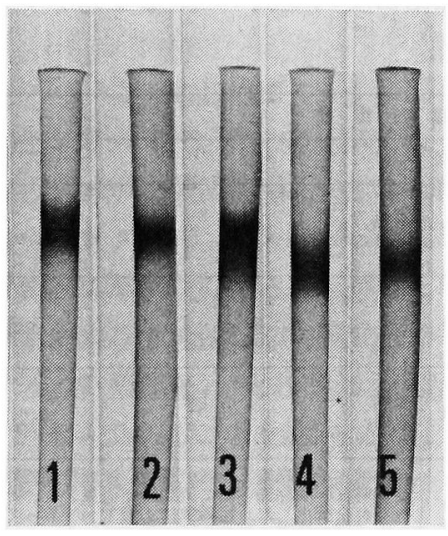

1. 正常腎 膜結合性フリルアミダーゼ

2. 正常タイプの腎細胞癌 膜結合性アリルフミダ 一世

3. 正常タイプと胎盤型腎細胞癌 膜結合性フリル フミダーゼ

4. 胎盤型腎細胞癌 膜結合性フリルアミダーゼ

5. 胎盤膜結合性アリルアミダーゼ

図1、ポリアクリルアミドゲル電気泳動像
なお第 $1 ， 2$ 症例で肉眼的に正常腎組織部分由来 のMb-AAを電気泳動すると，No.1の正常腎由来 のMb-AA と重なるバンドのみが認められた．表 1 に示すように胎盤由来のMb-AA と一致する位 置にバンドを認めた症例は，すべて近接あるいは 遠隔転移が証明された。また第 1 症例の剖検時に 得た肝転移癌組織由来のMb-AAは, 原発癌組織 由来の Mb-AA と 同様の，すなわち胎盤型 $\mathrm{Mb}-\mathrm{AA}$ の電気泳動の易動度を示した。

\section{2. 癌細胞由来のMb-AAの酵素学的性筫}

第 1 症例を腎細胞癌の酵素材料として，正常腎 臓部および胎盤由来のMb-AAとの 酵素学的性質 を比較した．表 2 に示すようにカイネテックスの らえでは 3 者は区別できなかつた。しかし熱処理

表 2，腎細胞癌，正常腎および胎盤各組織由来の膜 結合性アリルアミダーゼの諸性質

\begin{tabular}{|c|c|c|c|}
\hline 醖嗉材料 & 督細胞峦 & 正 常 筩 & 胎 \\
\hline 子 & 24 万 & $24 \pi$ & 24 万 \\
\hline 道 $\mathrm{pH}$ & 7.25 & 7.25 & 7.25 \\
\hline Km値 (甚浜L-ala- $\beta$-naphthylamide) & $8.7 \times 10^{-5} \mathrm{M}$ & $8.7 \times 10^{-5} \mathrm{M}$ & $8.7 \times 10^{-5} \mathrm{M}$ \\
\hline Ala- $\beta$-NA/Leu- $\beta$-NAの活性比 & 2.3 & 2.4 & 2.2 \\
\hline L-メチオニンImMの阻害乎 & $50 \%$ & $50 \%$ & $50 \%$ \\
\hline 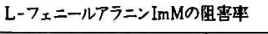 & $55 \%$ & $55 \%$ & $55 \%$ \\
\hline EDTAによる50\%阻羓瀆股 & $4 \times 10^{-5} \mathrm{M}$ & $4 \times 10^{-5} \mathrm{M}$ & $4 \times 10^{-4} \mathrm{M}$ \\
\hline 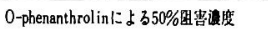 & $2.5 \times 10^{-3} \mathrm{M}$ & $2.5 \times 10^{-3} \mathrm{M}$ & $2.5 \times 10^{-3} \mathrm{M}$ \\
\hline 尿素による50\%组害渡度 & $0.8 \mathrm{M}$ & $0.8 \mathrm{M}$ & $0.8 \mathrm{M}$ \\
\hline
\end{tabular}

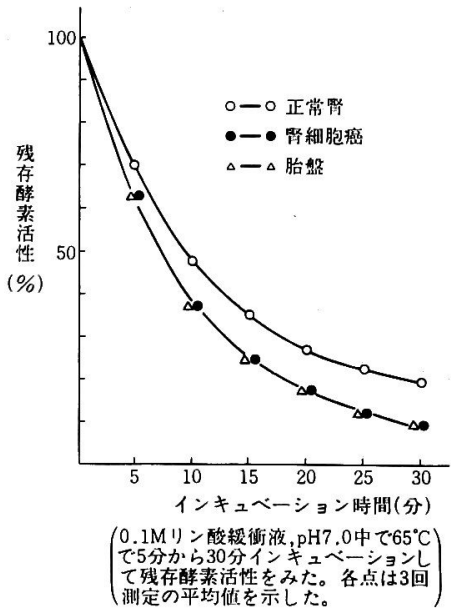

図 2 . 耐熱性 $\left(65^{\circ} \mathrm{C}\right)$ 


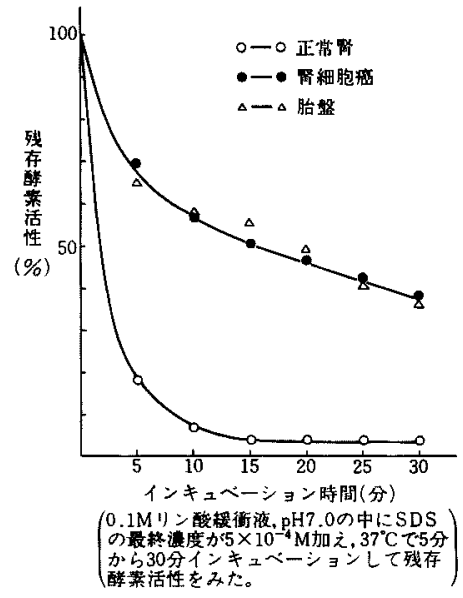

四了，SDSに上る醉素の失活

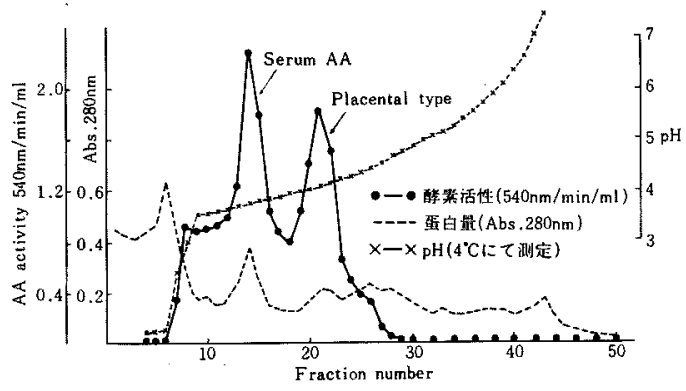

図 4. 腎細胞癌患者腹水のisoelectric focusing

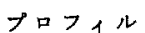

とSDS処理による䣼蛋白変性に基づく活性の低 下を調べると，腎細胞癌由来のMb-AAと正常腎 由来のMb-AAとの間に違いが認められた。図 2

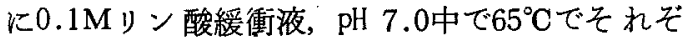
れの酵素材料をインキニベーションした時の残存 酵素活性の時間的変化を示した，腎細胞癌由来 のMb-AAは 正常腎由来のMb-AAよりる熱に弱 く, 胎盤由来のMb-AAと一致した. SDS処理は $0.1 \mathrm{M}$ リン酸緩衝液, $\mathrm{pH} 7.0$ の中にSDSを $5 \times 10^{-4} \mathrm{M}$ になるように加え, $37^{\circ} \mathrm{C} て ゙ 5$ 分から30分インキュ ベーションして酵素活性の低下をみた。 また図 3 に示すように，腎細胞癌由来のMb-AA と胎盤由来 のMb-AAのSDSに対する 抵抗性は正常腎由来の Mb-AAよりも強かつた.

\section{3. 腎細胞癌患者血清と腹水中への胎盤型Mb- $\mathbf{A A}$ の出現}

第 1 症例の患者腹水と血清から精製した酵素材 料をそれぞれisoelectric focusingを行ない，両者と もに胎盤型Mb-AAを証明した，図 4 はisoelectric focusingによる腹水中のフリルアミダーゼのパタ ーンである. 右側のやや小さいピークが胎盤型 $\mathrm{Mb}-\mathrm{AA}$ と分子量, 等電点, $\mathrm{Km}$ おびディスク電 気泳動の易動度がすべて一致した。左側の大きな ピークは正常血清中のアリルフミダーゼである.

患者血清中にも腹水中よりも量は少ないが胎盤型 Mb-AAを証明できた。

\section{考察}

癌細胞中に胎児型アイソェンザイム，あるいは 胎盤型アイソェンザイムが認められることは多く の酵素で証明されている9．私達は腎細胞癌組織 より、トリプシンにて容出したMb-AAアイソェ ンザイムが 胎盤型を示したことはすでに 報告し た2)3)4.

本研究に打いては，さらに腎細胞癌患者の症例 を增し，胎盤型Mb-AAの出現頻度や悪性度との 関連などについて研究を進めた。第 1 症例を含む 7 症例中 5 例，すなわら $71 \%$ の高率で腎細胞癌組 織中に胎盤型Mb-AAの出現を認めた。しかし正常 腎由来のMb-AA しか認めなかつた 2 症例では， 近接あるいは遠隔いずれの転移も手術時には認め ず，腎被膜内に腎細胞癌組織は限局していた。こ れに対して，胎盤型Mb-AAを証明した 5 症例で は全例腎被膜外への浸潤を組織学的にあるいは手 術時に認めた，組織型は 7 症例全例淡明細胞癌で あつた。したがつて組織型の上では同じであつて も，私達の成績から胎盤型Mb-AAの出現を証明 でさた癌組織では，そうでない癌組織より悪性度 が高い可能性が考えられる。

腎細胞癌中の胎盤型に偏倚したMb-AAは，分 子量打よび種々のカイネティックスの成績からは 正常腎や胎盤由来のMb-AAとは区別できなかつ た。しかし腎細胞癌由来の胎盤型Mb-AAは電気 泳動の易動度, 等電点, 耐熱性やSDSに対する失 
活の程度などから，正常腎由来のMb-AAと明確 に区別できたが，胎盤由来のMb-AA とは前記の 諸性質に関しても完全に一致していた。 また第一 症例の血清 と腹水中に胎盤型Mb-AAが出現して いることを証明できた，腎細胞癌組織の膜成分か らトリプシンで溶出したMb-AAの 分子量が, 血 清や腹水中で証明されたMb-AAと区別できない ことや，等電点，耐熱性およびSDS処理による失 活の程度などの点でも完全に一致することから，

トリプシン処理で溶出して得た醭素が人工産物で なく, 天然の型の酵素であることが強く示唆され た. 上記の成績から癌細胞中で胎盤型に偏倚した Mb-AAは，現段階では新しいアイソェンザイム であると思われる．私達は第 1 㱏例の患者名にら なみ，癌細胞中に新しく出現してきたMb-AA イソェンザイムにShiba-isoenzyme と命名した。

\section{まとめ}

1）腎細胞癌患者 7 名のうち，5名の癌組織か ら胎盤型膜結合性フリルアミダーゼの出現を認め た.

2）胎盤型膜結合性アリルアミダーゼの出現を 認めた 5 症例全例に，手術時近接あるいは遠隔い ずれかの転移巣を認めた．他方正常腎型膜結合性 フリルアミダーゼしか認められなかつた 2 症例で は, 組織学的にも手術時にも被膜外への転移は認 められなかつた。

3）癌組織から胎盤型膜結合性フリルフミダー ゼの出現を認めた 1 例の患者の腹水および血清か らも，本酵素を証明した。

4）癌細胞中に新しく出現してきた胎盤型膜結 合性アリルアミダーゼを，患者名にちなんで
Shiba-isoenzyme と命名した.

椠辞本研究の一部は病熊代謝研究会 (昭和53年度) 打 よび日本応用醅素協会（昭和53年度）からの援助を5け

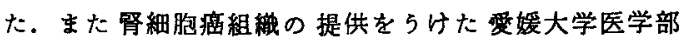
泌尿器科竹内正文教授，高羽津助教授に感碀いたしま す.

\section{文献}

1) Hiwada $K$, et al: Comparison of human membrane-bound neutral arylamidases from small intestine, lung, kidney, liver and placenta. Clin Chim Acta 76: 267, 1977.

2) Hiwada $K$, et al: Placental form of membrane-bound neutral arylamidase found in renal cell carcinoma. Clin Chim Acta 79: $569,1977$.

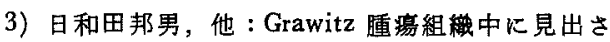
れた胎盤型瞙結合性中性 フリルアミダーゼ. 医 学のあゆみ 101：540，1977.

4）国府達郎，他：胎盤型膜結合性中性 アリルア ミダーぜを産生した Grawitz 腫痬の 1 例. 代謝 $1223,14: 1977$.

5)松谷衛, 他：新血清ロイシンアミノベブチ

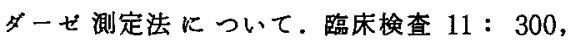
1967.

6) Wachsmuth ED and Donner P: Conclusions about aminopeptidase in tissue sections from studies of amino acid naphthylamide hydrolysis. Histochemistry 47: 271, 1976.

7) Lowry $\mathrm{OH}$, et al: Protein measurement with Folin phenol reagent. J Biol Chem 193: 265, 1951.

8) Hiwada K, et al: A placental type of membrane-bound arylamidase in serum and ascites from a patient with renal cell carcinoma. Clin Chim Acta 88: 311, 1978.

9）東野一弥：癌胎児性アインザイム。蛋白質核 酸醉素 $23: 594,1978$. 